ENCYCLOPEDDIE Encyclopédie berbère

BERBERE

1 | 1984

1 | Abadir - Acridophagie

\title{
Abū Yūsof Ya'qūb el-Mansūr
}

(Voir Almohades)

C. Agabi

\section{OpenEdition}

\section{Journals}

Édition électronique

URL : http://journals.openedition.org/encyclopedieberbere/805

DOI : $10.4000 /$ encyclopedieberbere.805

ISSN : 2262-7197

Éditeur

Peeters Publishers

Édition imprimée

Date de publication : 1 novembre 1984

Pagination : $95-96$

ISBN : 2-85744-201-7

ISSN : $1015-7344$

Référence électronique

C. Agabi, «Abū Yūsof Ya'qūb el-Mansūr », Encyclopédie berbère [En ligne], 1 | 1984, document A34, mis en ligne le 01 décembre 2012, consulté le 05 octobre 2020. URL : http://journals.openedition.org/ encyclopedieberbere/805; DOI : https://doi.org/10.4000/encyclopedieberbere.805

Ce document a été généré automatiquement le 5 octobre 2020.

(c) Tous droits réservés 


\section{Abū Yūsof Ya'qūb el-Mansūr}

\section{(Voir Almohades)}

\section{Agabi}

1 Troisième calife almohade, Abū Yūsof Ya'qūb succède à son père Abū Ya'qūb Yusof en 1184, il régnera jusqu'en 1213, année où il abdiqua en faveur de son fils Yūsof el Monstancir. Sa mort semble avoir suivi de près cette décision. Sous son règne l'empire almohade atteint son apogée. El Mansūr dut d'abord rétablir l'autorité almohade au Maghreb central où un prince almoravide de Majorque, 'Ali Ibn Ghaniya s'était emparé de Bougie, de la Kalaa des Beni Hammad puis d'Alger et de Miliana; il assiégeait Constantine lorsque Abū Yūsof Ya'qūb intervint vigoureusement. Les Banu Ghaniya furent rejetés dans le Jerid. 'Ali fit alors alliance avec les Arabes Solaīm et Qaraqūš maîtres du Fezzan et de la Tripolitaine. Les alliés occupèrent presque toute l'Ifrīqiya, seuls Tunis et Mahdiya restèrent fidèles.

2 Abū Yūsof reprit Gafsa et Gabès mais, après son départ, 'Ali reprit l'offensive et, avec l'aide des contingents arabes et fezzanais, il se constitua un empire couvrant la totalité de l'Ifrīqiya, depuis la Tripolitaine jusqu'à Annaba et Biskra. Les Banu Ghaniya agissent d'autant plus facilement que les forces almohades sont alors engagées en Espagne où elles battent Alphonse VIII de Castille à Alarcos (1196).

3 La fin du règne fut plus pacifique et marquée par d'importantes constructions dans les principales villes, particulièrement à Marrakech. La personnalité d'El Mansūr reste peu connue mais il semble s'être détaché progressivement de la pure doctrine almohade. Il n'est pas impossible que son abdication soit en relation avec le malaise alors décelable à la cour de Marrakech en raison de ces variations doctrinales. 


\section{BIBLIOGRAPHIE}

Voir Almohades.

INDEX

Mots-clés : Algérie, Biographie, Espagne, Maroc, Moyen Âge 